Check for updates

Cite this: RSC Adv., 2017, 7, 43938

Received 22nd June 2017

Accepted 5th September 2017

DOI: 10.1039/c7ra06960j

rsc.li/rsc-advances

\section{Improved corrosion resistance and antibacterial properties of composite arch-wires by $\mathrm{N}$-doped $\mathrm{TiO}_{2}$ coating $\dagger$}

\author{
Jiming Liu, ${ }^{a}$ Yixin Lou, ${ }^{a}$ Chao Zhang, ${ }^{b}$ Shuo Yin, ${ }^{c}$ Hongmei Li, ${ }^{d}$ Daqin Sun ${ }^{d}$ \\ and Xinhua Sun (D)*a
}

\begin{abstract}
In this paper, composite arch-wires (CAWs) coated with $\mathrm{TiO}_{2}$ and $\mathrm{N}$-doped $\mathrm{TiO}_{2}$ nanocrystal thin films were fabricated. We found that the corrosion resistance and antibacterial properties of CAWs can be significantly improved by coating with the $\mathrm{TiO}_{2}$ nanocrystal thin film, especially using the $\mathrm{N}$-doped $\mathrm{TiO}_{2}$ nanocrystal thin film, which is extremely important for their clinical application. The improved performances were confirmed by measuring potentiodynamic polarization curves and electrochemical impedance spectroscopy (EIS). The results revealed that $\mathrm{N}$-doped $\mathrm{TiO}_{2}$ coated CAWs can prolong the wearing time and improve the security of the arch wire in the oral cavity. In addition, the antibacterial activities of the samples were tested against Streptococcus mutans by bacterial culture. It was found that the CAWs coated with $\mathrm{N}$-doped $\mathrm{TiO}_{2}$ showed the highest antibacterial activity. Finally, the cytotoxicity of the samples was tested and evaluated, and the results showed that the CAWs modified with the $\mathrm{N}$-doped $\mathrm{TiO}_{2}$ nanocrystal thin film have great potential in practical dental treatment.
\end{abstract}

\section{Introduction}

In modern society, people pay more and more attention to oral beauty, and orthodontic treatment is an effective way to improve the arrangement of teeth. So far, several efficient and multi-functional orthodontic materials have been well developed. The composite arch wire (CAW) is one of the most important orthodontic materials which was developed by Daqian Sun et al. in 2011. ${ }^{1}$ CAW consists of a nickel-titanium shape memory alloy (TiNi SMA), and stainless steel (SS) arch wire which are laser-welded via a copper inter layer. ${ }^{2}$ CAW is a new type of orthodontic arch wire. At present, NiTi and SS arch wires are widely used in different stages of orthodontic treatment. Nickel titanium wire is used first, then the stainless steel wire is gradually utilized. In this way, the orthodontic treatment period is prolonged, which decreases the efficiency of the orthodontic treatment. Especially, the different stiffness and

${ }^{a}$ Department of Orthodontics, College and Hospital of Stomatology, Jilin University, No. 1500 Qinghua Road, Changchun 130021, People's Republic of China. E-mail: taogaozhuanyong@163.com; Tel: +86-431-88796023

${ }^{b}$ Department of Prosthodontics, Stomatology Hospital of Guangzhou Medical University, No. 39 Huangsha Road, Guangzhou 510140, People's Republic of China ${ }^{c}$ Changchun Stomatological Hospital, No. 2239 Dajing Road, Changchun 130021, People's Republic of China

${ }^{d}$ Key Laboratory of Automobile Materials, Ministry of Education, Department of Materials Science and Engineering, Jilin University, No. 5988 Renmin Street, Changchun 130025, People's Republic of China

$\dagger$ Electronic supplementary information (ESI) available. See DOI: $10.1039 / \mathrm{c} 7 \mathrm{ra06960j}$ performance of the arch wires are needed in the different parts and different periods of the dental arch teeth. Thus, it cannot meet the clinical needs by using a single arch wire, and CAW can solve this problem. CAW can move the teeth with nickel titanium arch wires and provide anchorage with stainless steel wire. The power of the soft nickel titanium arch wires are directly used on the dislocation tooth to move tooth effectively, while the rigidity of stainless steel wires are used to strengthen anchorage teeth stability and prevent the negative moving. Then, CAW combines the advantages of each material to correct the malposition of the tooth which can improve the treatment efficiency and shorten the course of treatment.

Recent research demonstrated that copper $(\mathrm{Cu})$ can obviously improve the mechanical property of the CAW when it is used as the welding transition layer. ${ }^{3,4}$ Compared with NiTi shape memory alloy and SS, Cu has a lower melting point and a decent strength; thus $\mathrm{Cu}$ exhibits excellent ductility and deformation capacity, which makes the joint flexible and ductile. The joint tensile strength and the shape recovery ratio of NiTi alloy can be greater than $520 \mathrm{MPa}$ and $98 \%$, respectively, which can meet the requirements of clinical performance. ${ }^{5}$

The selection of materials for dental applications depends upon a number of factors such as corrosion behavior, mechanical properties, biocompatibility and aesthetic value. The corrosion behavior of metallic materials is usually the most important property, because biocompatibility and cytotoxicity are dependent on the products of the corrosion process. It has been reported that $46 \%$ of the orthodontic patients will occur demineralization within 12 months who are treated with fixed 
appliance. ${ }^{6}$ The main reason of demineralization during orthodontic treatment with fixed appliance is attached dental plaque. It has been reported that after using fixed appliance for 1 to 3 weeks, the proportion of streptococci mutans in dental plaque increased one time. Note that the difference is significant, and the corrosion of the metals in which played an important role, which had been found to induce specific changes in the oral environment, such as decreasing $\mathrm{pH}$ and increasing dental plaque accumulation. The increase in the number of lactobacilli and Streptococcus mutans will decrease the $\mathrm{pH}$ value in the mouth, which is contributed to tooth demineralization when pathological changes occurred. ${ }^{7}$ Traditional preventive methods of enamel demineralization include proper tooth brushing, fluoride rinse or varnishes, ${ }^{8}$ a fluoridereleasing bonding system, ${ }^{9}$ acidulated phosphate fluoride (APF) foam or gel, ${ }^{10}$ and using acid etching area. ${ }^{11}$ However, these approaches require good cooperation with orthodontic patients, and the drug concentration is difficult to maintain. The complicated procedures would make clinical treatment more difficult. Our group has performed a large number of experimental studies on CAW, and we found that CAW has no obvious antimicrobial properties and its corrosion resistance is also slightly lower than those of two base materials. In order to improve the corrosion resistance and antibacterial properties of CAW, we attempt to deposit $\mathrm{TiO}_{2}$ and $\mathrm{N}$-doped $\mathrm{TiO}_{2}$ nanocrystal thin films on the surface of CAWs to improve their performance.

Until now, the nanotechnology has been widely used in the biomedical field. Titanium dioxide, as a photo-catalytic antibacterial material, has considerable beneficial properties: chemical stability, biocompatibility, high potential for selfcleaning, and high antibacterial activity. ${ }^{12-17}$ But $\mathrm{TiO}_{2}$ is a wide-band gap semiconductor ( $3.2 \mathrm{eV}$ for anatase $\left.\mathrm{TiO}_{2}\right)$, and it can only absorb UV light $(\leq 387 \mathrm{~nm})$, so only a small part $(\sim 5 \%)$ of solar light can be utilized. ${ }^{18}$ Asahi et al. reported that N-doped $\mathrm{TiO}_{2}$ has obvious catalytic activity under visible light irradiation compared with pure $\mathrm{TiO}_{2} \cdot{ }^{19}$ It was confirmed that N-doping can extend the absorption edge of $\mathrm{TiO}_{2}$ to the visible region, and narrow the band gap, ${ }^{20}$ thus enhancing the photo-catalytic antibacterial ability of $\mathrm{TiO}_{2} \cdot{ }^{21}$ In general, since understanding of new materials is often inadequate, medical workers often need to carry out in vitro experiments to select the appropriate material. For dental materials, the saliva in oral cavity is the basic corrosion environment which we simulated for studying corrosion resistance and antibacterial properties of CAWs in vitro. Radio frequency (RF) magnetron sputtering is an effective method due to its inherent multi functionality, uniform surface coverage and low-temperature deposition. ${ }^{22,23}$ The main advantage of magnetron sputtering is able to deposit inorganic nanoparticle thin films with controllable size and shape by tuning preparation parameters. ${ }^{24}$

The newly developed CAWs with excellent mechanical properties have great potential for orthodontic applications, ${ }^{25}$ but the corrosion resistance and antibacterial performance of CAW are still not satisfactory. In this study, in order to further improve the anticorrosion ability and antibacterial activity of CAWs, $\mathrm{TiO}_{2}$ and $\mathrm{N}$-doped $\mathrm{TiO}_{2}$ nanocrystal thin films are respectively deposited on the CAW surface. The modified samples were then exposed to artificial saliva to simulate common conditions in the oral cavity in order to investigate their anticorrosion ability. The antibacterial activity was also studied by potentiodynamic polarization curves and EIS. Streptococcus mutans culture in the samples' extract was studied to evaluate the antibacterial properties of the samples.

\section{Experimental}

\subsection{Materials and sample preparation}

Ti-44.73 wt\% NiTi SMA wire (Smart Co., Beijing, China), Fe$18 \mathrm{Cr}-8 \mathrm{Ni}$ (SS), and pure $\mathrm{Cu}$ were used as the base metals in this paper. The dimensions of the wires were $15 \mathrm{~mm}$ (length) $\times$ $0.64 \mathrm{~mm}$ (width) $\times 0.48 \mathrm{~mm}$ (thickness). The thickness of the pure $\mathrm{Cu}$ interlayer was $0.2 \mathrm{~mm}$. The base metal was ground using silicon carbide (SiC) papers of 600, 1000, 1500, 2000 and 5000 grit to remove the oxide layer and was then ultrasonically degreased in acetone. The NiTi SMA and SS wires were fixed end-to-end in a self-constructed apparatus with a pure $\mathrm{Cu}$ interlayer. A Nd:YAG laser welding system (HKW-1050) with a wavelength of $1064 \mathrm{~nm}$ was used for welding. The optimized laser parameters used in the study were as follows: current, 75 A; pulse width, $5.0 \mathrm{~ms}$; rate, $1.0 \mathrm{~Hz}$; defocusing amount, $2.3 \mathrm{~cm}$.

\subsection{Film preparation}

The CAWs were used as sputtering substrate which were ultrasonically cleaned in $99.5 \%$ acetone, 99\% ethanol and deionized water for $30 \mathrm{~min}$, and were dried under nitrogen flow. $\mathrm{TiO}_{2}$ nanoparticle thin films were deposited by RF magnetron sputtering method, with $99.99 \%$ ceramic $\mathrm{TiO}_{2}$ as the target. A mixture of $\mathrm{Ar}$ and $\mathrm{N}_{2}$ (gas flow ratio of Ar to $\mathrm{N}_{2}$ was $30: 1$ ) was used as the sputtering gas for $\mathrm{N}$-doped $\mathrm{TiO}_{2}$ film and pure $\mathrm{Ar}$ was used as the sputtering gas for pristine $\mathrm{TiO}_{2}$ film. The RF sputtering power was $120 \mathrm{~W}$. The background temperature was $300{ }^{\circ} \mathrm{C}$ and the sputtering time was $180 \mathrm{~min}$. The chamber pressure was pumped to $1.0 \times 10^{-4} \mathrm{~Pa}$, and the working pressure was maintained at 1.0 to $1.2 \mathrm{~Pa}$ during the film growth. The target was pre-sputtered for $10 \mathrm{~min}$, in order to remove any contamination. After sputtering, all samples were annealed in air at $450{ }^{\circ} \mathrm{C}$ for $2 \mathrm{~h}$.

\subsection{Characterizations}

$\mathrm{X}$-ray diffractometer (D8, Bruker, Germany) with $\mathrm{Cu} \mathrm{K} \alpha$ radiation $(\lambda=1.5406 \AA)$ was employed to detect the crystal structure of the coating materials. The X-ray photoelectron spectroscopy (XPS) was measured by a Thermo ESCALAB 250 instrument, coupled with $\mathrm{Al} \mathrm{K} \alpha$ radiation (VG Scientific, UK). The surface morphology of the sample was observed by scanning electron microscope (SEM S-4800 EDAX AMETEK, USA) with an energy dispersive spectrometer (EDS) analyzer (Genesis-2000 AMETEK, USA).

\subsection{Electrochemical measurements}

Electrochemical tests were performed by CHI820 electrochemical workstation ( $\mathrm{CH}$ Instruments, Shanghai, China) with artificial saliva (AS) as the electrolyte. The composition of AS 
Table 1 Composition of the modified Fusayama AS

\begin{tabular}{ll}
\hline Component & Concentration $\left(\mathrm{mg} \mathrm{L}^{-1}\right)$ \\
\hline $\mathrm{NaCl}$ & 400 \\
$\mathrm{KCl}$ & 400 \\
$\mathrm{CaCl}$ & $\cdot 2 \mathrm{H}_{2} \mathrm{O}$ \\
$\mathrm{KSCN}$ & 795 \\
$\mathrm{NaHPO}_{4} \cdot \mathrm{H}_{2} \mathrm{O}$ & 300 \\
$\mathrm{Na}_{2} \mathrm{~S} \cdot 9 \mathrm{H}_{2} \mathrm{O}$ & 690 \\
Urea & 5 \\
& 1000
\end{tabular}

electrolyte solution is listed in Table 1 . The counter electrode was a rectangular platinum plate, and the reference electrode was a saturated calomel electrode and the CAW samples were used as working electrode. Rubbing down all the samples with SiC papers to guarantee consistent surface roughness, then they were coated with epoxy resin, with an exposed active surface area of $20 \times 0.64 \mathrm{~mm}^{2}$. After an initial delay of $60 \mathrm{~min}$ to achieve the steady state, the scanning rate was $1 \mathrm{mV} \mathrm{s}^{-1}$, starting from $-1 \mathrm{~V}$ per SCE. The potentiodynamic polarization measurements were taken between -1000 and $+1000 \mathrm{mV}$. Electrochemical impedance spectroscopy (EIS) was tested by an AUTOLAB PGSTAT302N workstation.

\subsection{Antibacterial test}

Streptococcus mutans were chosen as standard bacteria. Separated suspensions of the bacteria were prepared at a concentration of $1.5 \times 10^{6}$ colony-forming units (CFU) per mL each. $100 \mu \mathrm{L}$ of each suspension was added to $3 \mathrm{~mL}$ of liquid medium in tube to make the suspension of bacteria. The suspensions were divided into four groups. The first test substrate (coated with $\mathrm{N}$ doped $\mathrm{TiO}_{2}$ thin film), the second test substrate (coated with the $\mathrm{TiO}_{2}$ thin film) and control substrate (pristine substrate) were placed into these suspensions, which were incubated at $37^{\circ} \mathrm{C}$ for $24 \mathrm{~h}$ under visible light irradiation a thermostatic light incubator and a xenon lamp (MICROSOLAR 300, Beijing Perfect light Co., Ltd) was used as the visible light source in our research, with all the UV light below $420 \mathrm{~nm}$ being removed with a glass filter. And the substrates were kept $20 \mathrm{~cm}$ away from the light source. After incubation and vigorously shaking, $100 \mu \mathrm{L}$ of each suspension was taken and added to $10 \mathrm{~mL}$ of sterile saline for dilution. Then, $100 \mu \mathrm{L}$ of the diluted solution was added to cooled $\left(55^{\circ} \mathrm{C}\right)$ solid medium, which was vigorously shaken and then poured into a Petri dish. The solid medium was cultured at $37^{\circ} \mathrm{C}$ for $24 \mathrm{~h}$, after which the numbers of colonies on each plate were counted. This procedure was repeated three times.

\section{Results and discussion}

\subsection{Structural characterization}

The CAW consists of SS and NiTi arch wire by laser welding via a pure copper interlayer. Fig. 1a shows SEM image of the microstructure of CAW welding zone. The surface of the welding zone is very flat and smooth without obvious defects and welding marks. According to EDS elemental mapping images in
Fig. $1 \mathrm{~b}-\mathrm{f}$, the Ni and Ti contents from top to bottom gradually reduced, whereas Fe and $\mathrm{Cr}$ element increased. $\mathrm{Cu}$ is the main element in the welding area; thus $\mathrm{Cu}$ element spreads homogeneously, while $\mathrm{Ni}, \mathrm{Ti}, \mathrm{Fe}$ and $\mathrm{Cr}$ are distributed gradually and there is no obvious boundary between them which indicated that five types of metals were fused together under the action of laser, as shown in Fig. 1b-f. So the laser-welded composite arch wire is sturdy and durable in this paper.

XRD was used to detect the crystal structure and calculate the crystal size of the coating materials, i.e. $\mathrm{TiO}_{2}$ and $\mathrm{N}$-doped $\mathrm{TiO}_{2}$ nanoparticle thin films. After calcination at $450{ }^{\circ} \mathrm{C}$ for $2 \mathrm{~h}$, their XRD patterns were measured and shown in Fig. 2. The diffraction peaks of $\mathrm{TiO}_{2}$ and $\mathrm{N}$-doped $\mathrm{TiO}_{2}$ are in good agreement with those of the standard anatase $\mathrm{TiO}_{2}$, indicating $\mathrm{TiO}_{2}$ and $\mathrm{N}$ doped $\mathrm{TiO}_{2}$ nanoparticle thin films have high crystallinity and an anatase structure. According to the Scherrer equation, the crystal sizes of $\mathrm{TiO}_{2}$ and $\mathrm{N}$-doped $\mathrm{TiO}_{2}$ thin films were calculated to be around $16 \mathrm{~nm}$, confirming that $\mathrm{TiO}_{2}$ and $\mathrm{N}$-doped $\mathrm{TiO}_{2}$ thin films are composed of $\mathrm{TiO}_{2}$ nanoparticles.

The XPS was used to identify the various elements in the thin films. Fig. 3a shows two survey XPS spectra of $\mathrm{TiO}_{2}$ and $\mathrm{N}$-doped $\mathrm{TiO}_{2}$ nanoparticle thin films. The XPS spectrum of pristine $\mathrm{TiO}_{2}$ is composed of $\mathrm{Ti}, \mathrm{O}$ and a contaminated carbon. From highresolution XPS spectra of $\mathrm{Ti} 2 \mathrm{p}$ (see Fig. 3b), the full width at half maximum of $\mathrm{Ti} 2 \mathrm{p}$ for $\mathrm{N}-\mathrm{TiO}_{2}$ was remarkably greater than that of pure $\mathrm{TiO}_{2}$ which indicated that the chemical composition and structure of $\mathrm{N}-\mathrm{TiO}_{2}$ are more complex than those of pure $\mathrm{TiO}_{2}$. The nitrogen doped into $\mathrm{TiO}_{2}$ may contribute it. But chemical shift of Ti $2 \mathrm{p}$ is not significant, indicated that the main component of thin film was still $\mathrm{TiO}_{2}$. Fig. $3 c$ shows the Ti 2p XPS peaks of the $\mathrm{N}$-doped $\mathrm{TiO}_{2}$ films. The Ti 2p peak was located at $458.7 \mathrm{eV}$ and $464.4 \mathrm{eV}$, which resulted from $\mathrm{Ti}^{4+}$ in $\mathrm{TiO}_{2}{ }^{26,27}$ Two other small peaks of $\mathrm{TiO}_{2}$ was observed at $457.8 \mathrm{eV}$ and $463.5 \mathrm{eV}$ which are attributed to the formation of $\mathrm{Ti}^{3+}$, because the outer electron of $\mathrm{Ti}$ is changed and oxygen atoms are replaced, indicating that oxygen vacancies existed in the sample. ${ }^{28,29}$ This result also means that oxygen vacancies may exist in $\mathrm{N}$-doped $\mathrm{TiO}_{2}$ thin film. Fig. $3 \mathrm{~d}$ shows the chemical binding state of $\mathrm{N}$ 1s for $\mathrm{N}$-doped $\mathrm{TiO}_{2}$ thin film. The XPS peak is observed at $400.1 \mathrm{eV}$, which can be attributed to interstitial N. ${ }^{30}$ According to the recent literature reports, the XPS peak locating at between 396 and $397.5 \mathrm{eV}$ is ascribed to $\mathrm{Ti}-\mathrm{N}-\mathrm{Ti}$ linkage which is due to doping of nitrogen atoms into a $\mathrm{TiO}_{2}$ lattice. ${ }^{31-34}$ Therefore, the XPS peak at $396.1 \mathrm{eV}$ can prove that the nitrogen element has been successfully incorporated into the $\mathrm{TiO}_{2}$ thin film by $\mathrm{Ti}-\mathrm{N}-\mathrm{Ti}$ linkage. In addition, the nitrogen content in the samples is about $1.34 \%$, as calculated by XPS.

SEM surface morphologies of $\mathrm{TiO}_{2}$ and $\mathrm{N}$-doped $\mathrm{TiO}_{2}$ coated CAWs are shown in Fig. $4 \mathrm{a}$ and b. $\mathrm{TiO}_{2}$ coated and $\mathrm{N}$-doped $\mathrm{TiO}_{2}$ coated CAWs exhibited different film morphologies, but both of them are very uniform. Their thicknesses are about $300 \mathrm{~nm}$. The morphology of $\mathrm{N}$-doped $\mathrm{TiO}_{2}$ coated CAW was changed significantly after $\mathrm{N}$ doping. Fig. 4a shows $\mathrm{TiO}_{2}$ coating, and its surface revealed a clear smooth polyhedral structure. The $\mathrm{N}$ doped $\mathrm{TiO}_{2}$ coating has significantly different membrane structure, and $\mathrm{TiO}_{2}$ particles have "blooming flower-like" appearance, ${ }^{35}$ as shown in Fig. 4 b. N-Doped $\mathrm{TiO}_{2}$ coated CAW is more uniform and dense than pristine $\mathrm{TiO}_{2}$ coated CAW. 

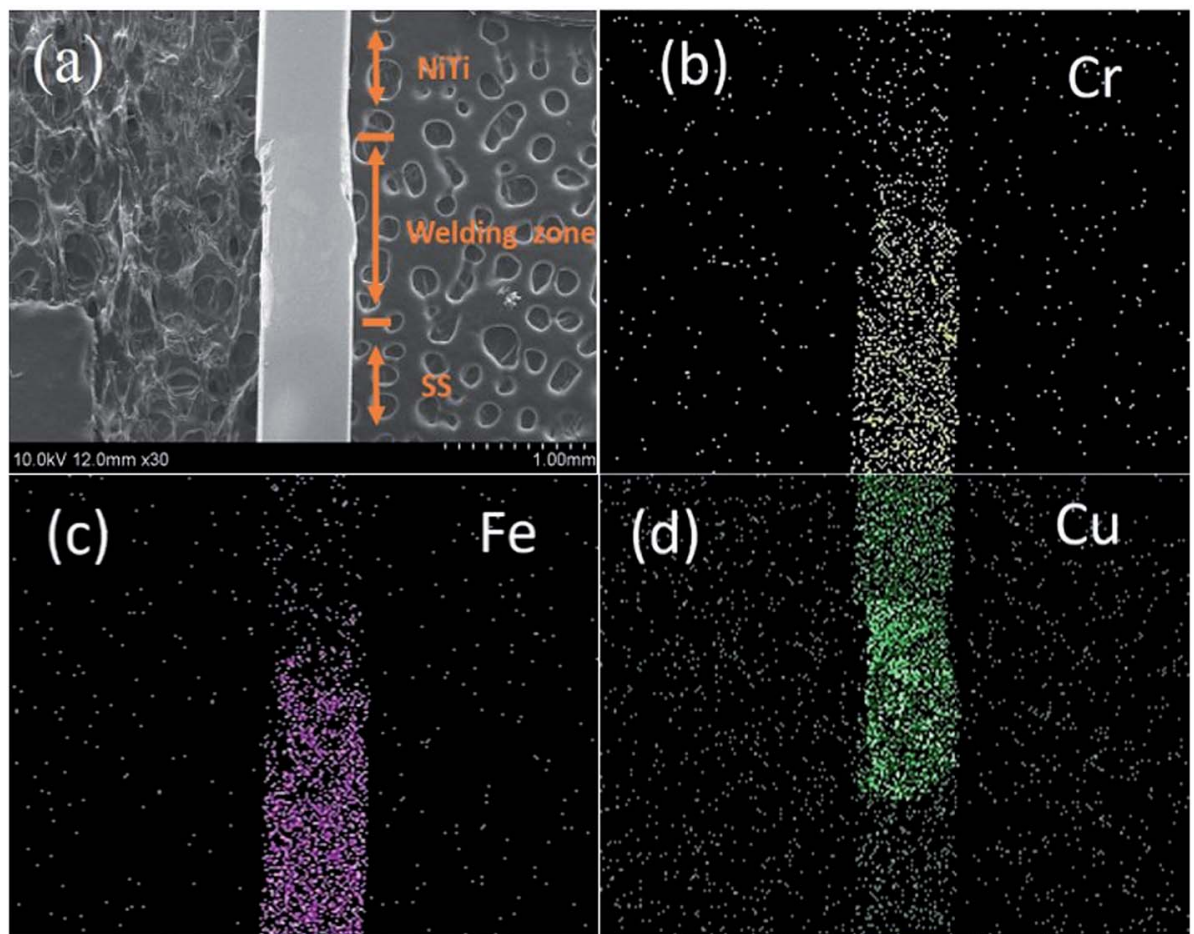

$\mathrm{Cu}$

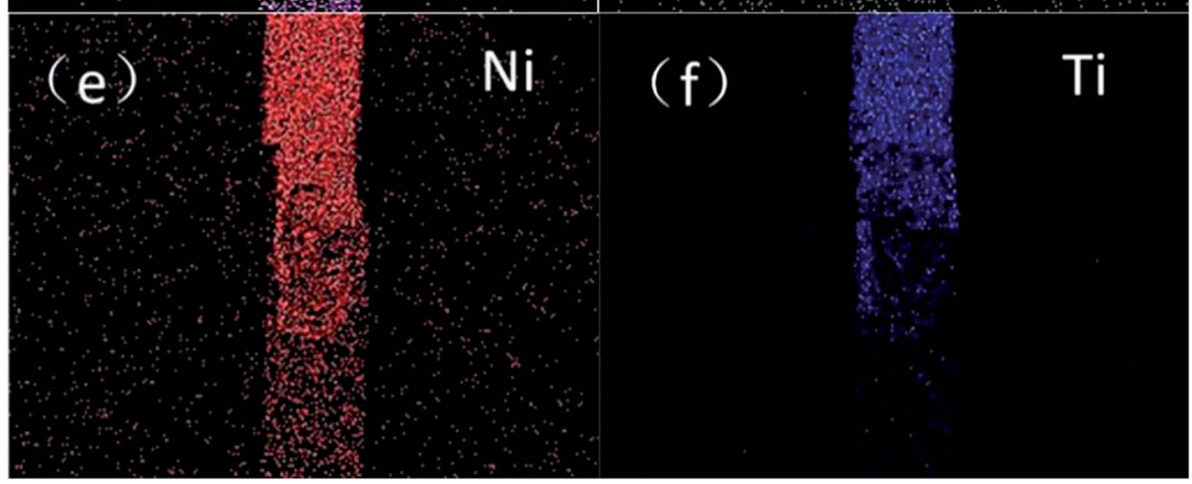

Fig. 1 SEM image (a) and the corresponding EDS mapping images of laser-welded composite arch wire (b-f).

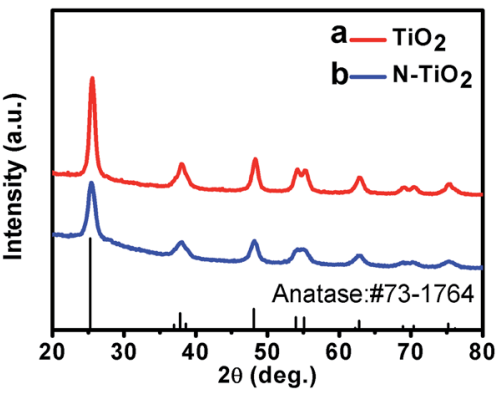

Fig. 2 XRD patterns of $\mathrm{TiO}_{2}$ (a) and $\mathrm{N}$-doped $\mathrm{TiO}_{2}$ (b) coated CAW samples.

\subsection{Corrosion resistance text}

The electrochemical performance of CAW is one of the most important performances when it is used as biomedical orthodontic material. ${ }^{36}$ So the corrosion behaviors of the different samples in the artificial saliva environment are evaluated. Fig. 5 presents three typical polarization curves of unmodified CAW, $\mathrm{TiO}_{2}$ coated CAW and $\mathrm{N}-\mathrm{TiO}_{2}$ coated CAW in AS solutions. In the lower potential of the polarization curve for pristine CAW in AS, vertical region represents the generation of hydrogen, and the smaller part of the slope represents the oxygen consumption. During the process of electrochemical experiments, the most of the metal will form an oxide film on the surface during the corrosion process. If the formed oxide film can prevent the further corrosion, it is called the passive process. But when the voltage continues to increase, the local passive oxide film will break, so that the obvious corrosion phenomenon occurs in the local area, this phenomenon is called pitting, and the potential of the occurrence is pitting potential $\left(E_{\text {pit }}\right)$. When the corrosion voltage exceeded the pitting potential, the current density increased rapidly, which indicated that the oxide film on the surface of the sample was broken, and the new corrosion happened. As shown in Fig. 5, for the polarization curve, all the cathode sections contain two sections, but in the anode polarization curve CAW showed a significant passive behavior, with 

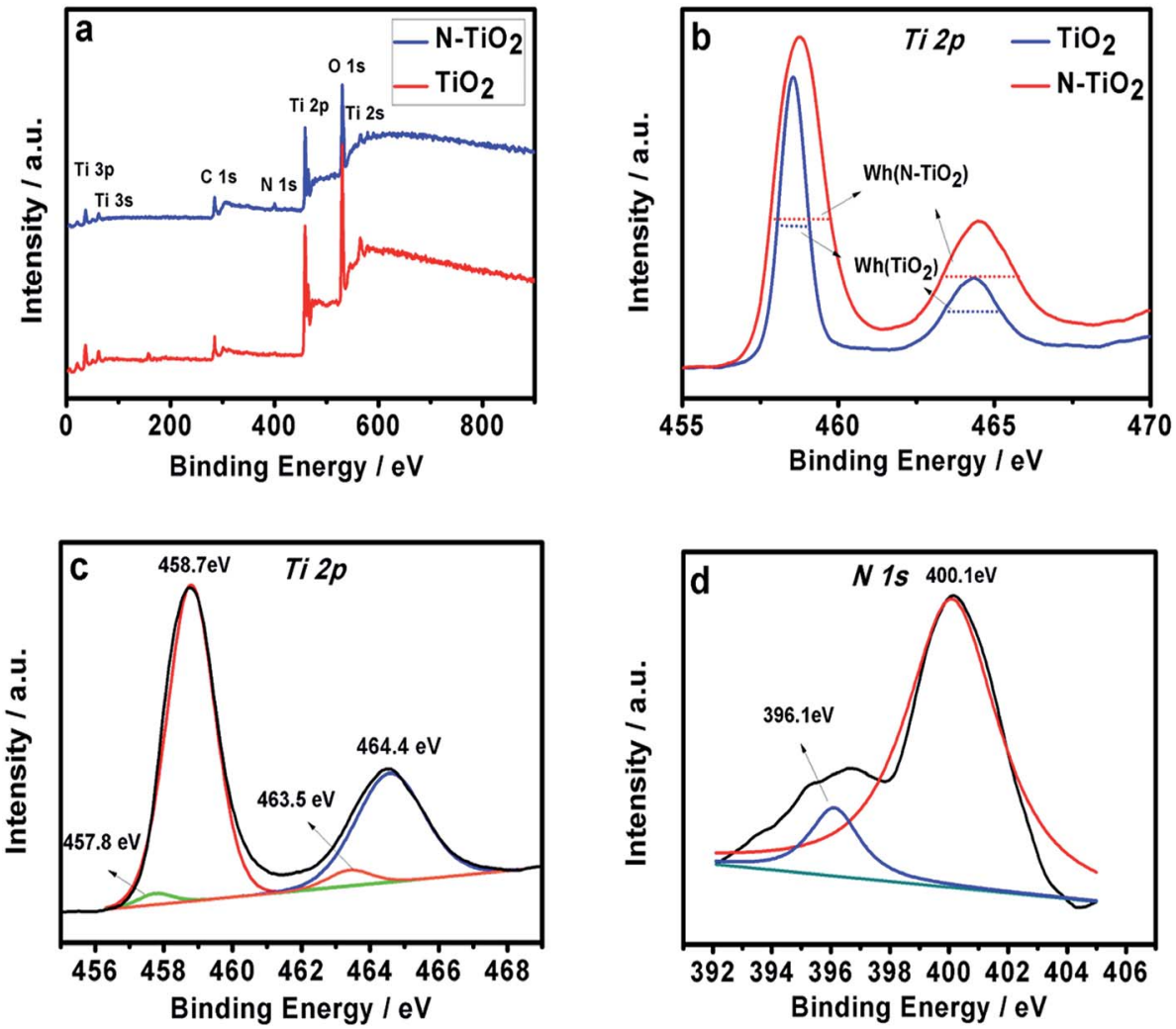

Fig. 3 (a) XPS survey spectra of $\mathrm{TiO}_{2}$ and $\mathrm{N}$-doped $\mathrm{TiO}_{2}$. High-resolution XPS spectra of Ti $2 \mathrm{p}$ peaks of $\mathrm{TiO}_{2}(\mathrm{~b})$ and $\mathrm{N}-\mathrm{doped} \mathrm{TiO} \mathrm{O}_{2}$ as well as $\mathrm{Ti} 2 \mathrm{p}$ (c) and $\mathrm{N}$ 1s (d) peaks of $\mathrm{N}-\mathrm{TiO}_{2}$.

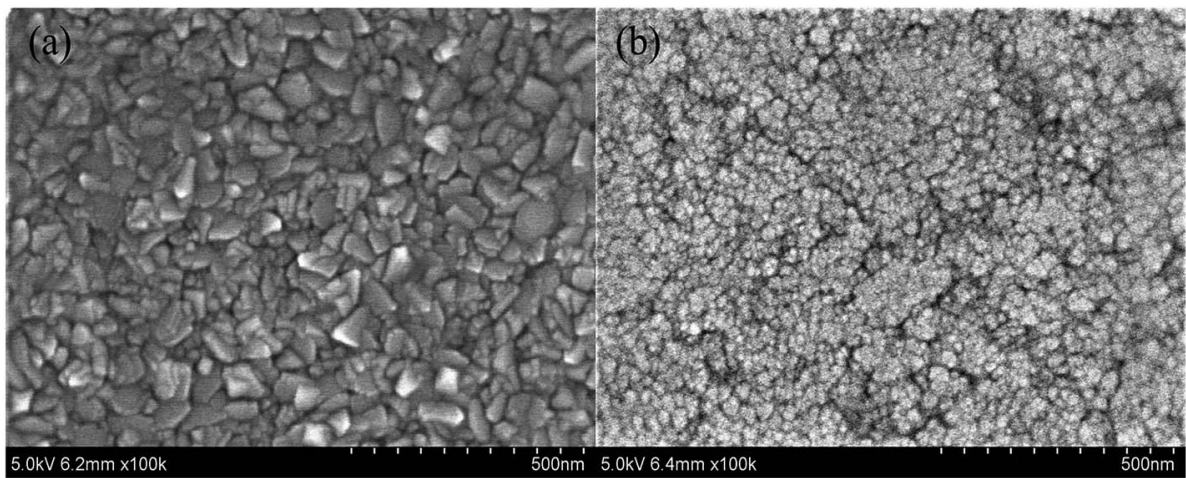

Fig. 4 SEM surface images of CAWs coated with $\mathrm{TiO}_{2}$ thin film (a) and $\mathrm{N}-\mathrm{TiO}_{2}$ thin film (b) after annealing at $450{ }^{\circ} \mathrm{C}$.

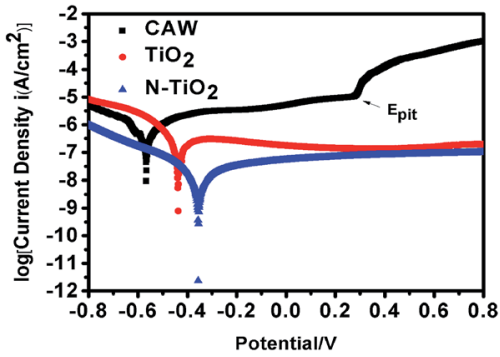

Fig. 5 Potentiodynamic polarization curves of pristine $\mathrm{CAW}, \mathrm{TiO}_{2}$ coat-CAW and $\mathrm{N}-\mathrm{TiO}_{2}$ coated CAW. a pitting potential $\left(E_{\text {pit }}\right)$ of $0.284 \mathrm{~V}$. When the corrosion voltage exceeded $0.284 \mathrm{~V}$, the current density of CAW increased rapidly, which indicated that the oxide film on the surface of CAW was broken, and the new corrosion occurred. But $\mathrm{TiO}_{2}$ and $\mathrm{N}-\mathrm{TiO}_{2}$ coated CAWs have no obvious anode area passive behavior and local pitting corrosion behavior was not observed. It indicated that $\mathrm{TiO}_{2}$ and $\mathrm{N}-\mathrm{TiO}_{2}$ coated CAWs have no oxide film rupture during electrochemical corrosion.

The corrosion process can be also evaluated by the corrosion potential $\left(E_{\text {corr }}\right)$ and corrosion current density $\left(I_{\text {corr }}\right)$ from the polarization curve. Generally, the higher corrosion potential $\left(E_{\text {corr }}\right)$ and lower corrosion current density $\left(I_{\text {corr }}\right)$ indicate that 
the sample has a low corrosion rate and good corrosion resistance. ${ }^{37,38}$ The corrosion behaviors of unmodified CAW as well as $\mathrm{TiO}_{2}$ and $\mathrm{N}-\mathrm{TiO}_{2} \mathrm{CAW}$ in artificial saliva were studied in detail by polarization and EIS techniques. There is a linear relationship in the strong polarization region between the current and voltage, the slope of the curve is called the Tafel slope. Corrosion potential and corrosion density can be obtained by the Tafel extrapolation method. The intersection of cathode and anode slope is the corrosion current value.

From Table 2, the $E_{\text {corr }}$ values of uncoated CAWs and $\mathrm{N}-\mathrm{TiO}_{2}$ coated CAWs were increased from -0.5659 to $-0.3557 \mathrm{~V}$, and the positive shifting of the $E_{\text {corr }}$ clearly shows an increase in corrosion resistance for $\mathrm{TiO}_{2}$ and $\mathrm{N}-\mathrm{TiO}_{2}$ coated samples. Another indicator of corrosion behavior is the corrosion current density $\left(I_{\text {corr }}\right)$, which is proportional to the rate of corrosion. The corrosion current density of CAW was measured as $5.620 \mu \mathrm{A}$ $\mathrm{cm}^{-2}$, while the corrosion current density of $\mathrm{TiO}_{2}$ and $\mathrm{N}-\mathrm{TiO}_{2}$ coatings were measured as $1.722 \mu \mathrm{A} \mathrm{cm}^{-2}$ and $0.8161 \mu \mathrm{A} \mathrm{cm}^{-2}$, respectively. The high corrosion potential means better corrosion resistance. Since corrosion current density is proportional to corrosion rate, lower corrosion current density also shows better corrosion resistance. Therefore, we can conclude that the corrosion rate of $\mathrm{N}-\mathrm{TiO}_{2}$ coated CAW is lower than those of pristine CAW and $\mathrm{TiO}_{2}$ coated CAW. This is due to its more dense surface coverage, as shown in Fig. 4; thus $\mathrm{N}-\mathrm{TiO}_{2}$ coating is more effective to prevent the contact between the electrolyte and the base metal material, and then hinder the occurrence of corrosion reaction. This result is also consistent with that of in Table 2. The protective rates of $\mathrm{TiO}_{2}$ and $\mathrm{N}-\mathrm{TiO}_{2}$ coatings were $69.36 \%, 85.47 \%$ respectively. The protection rate $(\eta)$ in Table 2 is calculated by the follow equation: ${ }^{39}$

$$
\eta=\left(I_{\text {corr }}^{0}-I_{\text {corr }}\right) / I_{\text {corr }}^{0} \times 100 \%
$$

where $I_{\text {corr }}^{0}$ represents the corrosion current density of CAW, and $I_{\text {corr }}$ represents the current density of coating samples. According to the results of polarization curves, the coating CAWs have more positive corrosion potential than unmodified CAW. Furthermore, N-doped $\mathrm{TiO}_{2}$ coating is better than pristine $\mathrm{TiO}_{2}$ coating.

$\mathrm{TiO}_{2}$ thin films exhibit ceramic based structures, which have low electrical conductivity and lower charge transport, thus improving the electrochemical barrier properties. Therefore, lowering the electron conductivity can delay the electrochemical process, and this is considered to be the electrochemical mechanism of corrosion resistance of $\mathrm{TiO}_{2}$ coated samples. In general, for a protective coating, in addition to strong corrosion resistance, the coating materials should be also separated completely the protecting base material and corrosive medium.

Table 2 Comparison of $E_{\text {corr, }} I_{\text {corr }}$ and $\eta$ on different surfaces

\begin{tabular}{llll}
\hline Sample & $E_{\text {corr }}(\mathrm{mV})$ & $I_{\text {corr }}\left(\mu \mathrm{A} \mathrm{cm}{ }^{-2}\right)$ & $\eta(\%)$ \\
\hline $\mathrm{CAW}$ & -565.9 & 5.620 & - \\
$\mathrm{TiO}_{2}$ & -434.1 & 1.722 & 69.36 \\
$\mathrm{~N}-T i O_{2}$ & -355.7 & $8.161 \times 10^{-1}$ & 85.47
\end{tabular}
between the coating and the substrate.

$\mathrm{TiO}_{2}$ nanoparticle coating thin films were prepared by magnetron sputtering. The coating surface is flat and compact with good sealing performance, which can effectively prevent corrosive medium to contact substrate material. At the same time from observation of the anodic passivation region of polarization curves, the formation of a dense passivation layer on the substrate surface limits the occurrence of the anodic reaction. $\mathrm{N}^{-\mathrm{TiO}_{2}}$ coating can more effectively enhance the corrosion resistance than pure $\mathrm{TiO}_{2}$ coating.

The corrosion current density obtained by Tafel extrapolation is not very accurate, and high speed scanning error or calculation of slope may lead to cathodic or anodic curve distortion, which will cause some errors to slope extrapolation corrosion current value. It can only roughly estimate the corrosion rate of samples, as well as the relative ranking of corrosion resistance. Thus the corrosion properties of different samples are further analyzed by the electrochemical impedance spectroscopy (EIS) diagrams. Fig. 6 shows the Nyquist, Bodephase and Bode-magnitude plots for unmodified, $\mathrm{TiO}_{2}$ coated and $\mathrm{N}$-doped $\mathrm{TiO}_{2}$ coated CAWs after immersing in artificial saliva for $30 \mathrm{~min}$ at open circuit potential. The high frequency capacitance behavior of the coating sample indicates the corrosion resistance, and the low frequency capacitance behavior indicates the capacitance process at the coating material/metal interface. According to the Nyquist plots, all of the plots are simple semicircular, indicating that each sample has a single time constant. The curves appear to have a similar shape, but they are very different in their sizes, which represents the number of charge transfer in the corrosion process. It also may explain the similar process occurring in all the coatings, but each case is carried out under different material surfaces. Compared with the unmodified CAW, the $\mathrm{TiO}_{2}$ and $\mathrm{N}$-doped $\mathrm{TiO}_{2}$ coated samples have a larger capacitance loop. It can be observed from the Nyquist plots the capacitance loop size of $\mathrm{N}$ doped $\mathrm{TiO}_{2}$ sample is about 2 orders of magnitude relative to CAW, is about 1 order of magnitude relative to $\mathrm{TiO}_{2}$ group. D. Y. $\mathrm{Yu}$ et al. pointed out that the larger the capacitance loop, the better the corrosion resistance of the layer. ${ }^{40}$ Therefore, $\mathrm{TiO}_{2}$ and $\mathrm{N}$-doped $\mathrm{TiO}_{2}$ coating can significantly improve the corrosion resistance of CAW, especially for the $\mathrm{N}^{-\mathrm{TiO}_{2}}$ coating. The improvement of the corrosion resistance of the material is due to the formation of a stable structure, effectively preventing the penetration of the electrolyte. The $\mathrm{TiO}_{2}$ nanoparticle coating produced by magnetron sputtering can effectively reduce the porosity of the material surface and form a sealed barrier, which can prevent the electrolyte to etch the substrate material. Thus, the permeation and corrosion of the electrolyte can be delayed, and the charge transfer resistance can be further increased which can enhance the barrier property for the corrosion protection of the substrate material. Therefore, low corrosion rates and high impedances obtained by electrochemical measurements confirmed that the $\mathrm{TiO}_{2}$ nanoparticle coating offered good barrier properties.

Besides Bode plots, phase angle plots are also provided to analyze the corrosion process. The high impedance modulus in 

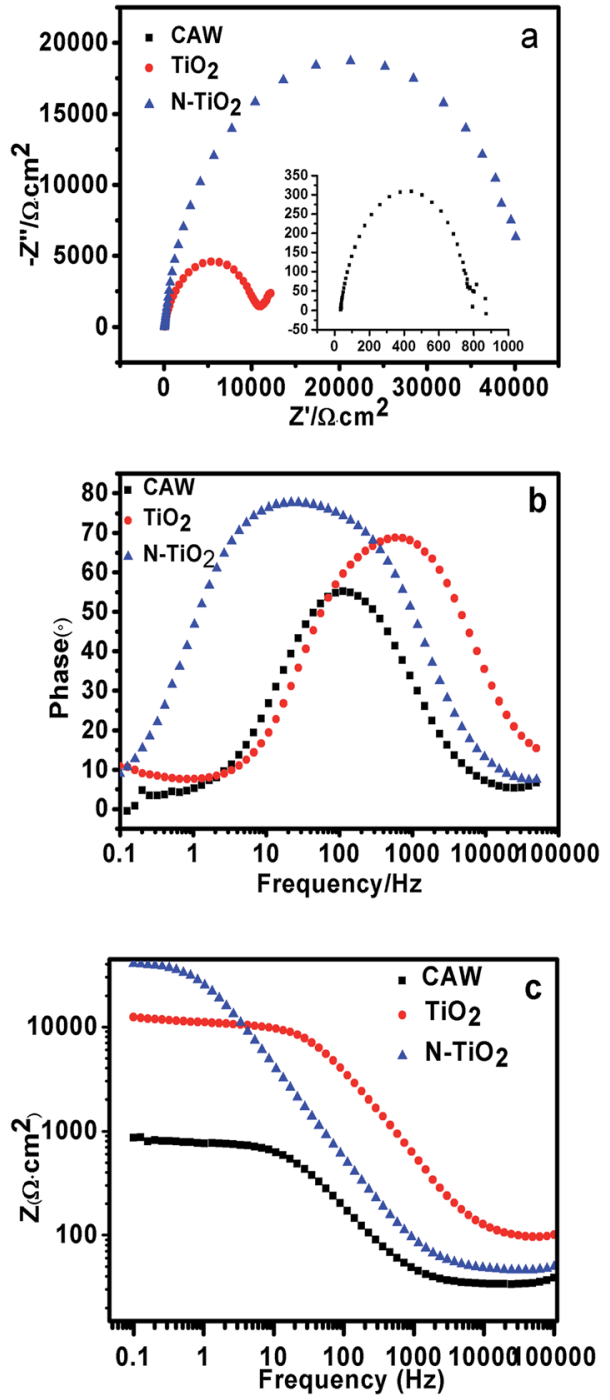

Fig. 6 EIS data of CAW and coated samples in AS after immersion for 30 min (a) Nyquist plots, (b) Bode phase plots and (c) Bode magnitude plots.

the low frequency region of the Bode diagram represents the barrier performance of the system. ${ }^{41}$ Low frequency high impedance modulus and one time constant revealed that the film has effective barrier property. ${ }^{42-44}$ In the Bode-phase plots, the higher phase angle and the low frequency impedance indicate the better corrosion resistance and passivity of the stable structure. At the same time it is believed that inert and homogenous film deposition can lead to higher phase angle and corrosion resistance. In Fig. $6 \mathrm{~b}$ and c, the coated samples have higher phase angle and low frequency impedance than CAW, especially for $\mathrm{N}-\mathrm{TiO}_{2}$.

Simple equivalent circuit of EIS electrochemical model was shown in Fig. 7. It was able to analyse impedance data accurately and understand corrosion mechanism further. By using the software Nova1.8 to fit equivalent circuit model, we found that it is the most suitable one for our results. The corresponding equivalent circuit principle diagram is presented in Fig. 7b. In this circuit, $R_{\mathrm{ct}}$ is the charge transfer resistance and

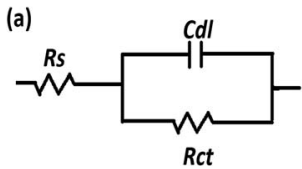

(b)

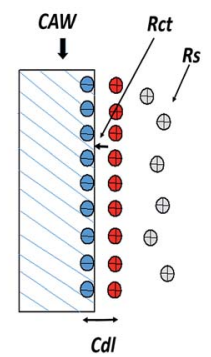

Fig. 7 (a) Equivalent circuit used for fitting the experimental data of $\mathrm{TiO}_{2}$ and $\mathrm{N}-\mathrm{TiO}_{2}$ coatings, (b) corresponding equivalent circuit principle diagram.

$C_{\mathrm{dl}}$ is the double layer capacitance that the corrosion reaction occurred at the coating material/substrate interface on the surface of CAW. In this case the most areas are well covered without corrosion, while $R_{\mathrm{S}}$ is the resistance of the solution. The data associated with the model are listed in Table 3.

As known, a good protective coating should be close to the base material as much as possible, so that the base material can be separated from corrosion medium completely. However, even a very dense coating, there also may exist some micro/ nano-porous structures. These small holes will form the channels from each other which allow small molecules of corrosive medium to pass and to corrode base materials. This kind of corrosion also occurred in our case. Although the nanoparticle coatings produced by magnetron sputtering are uniform and compact, artificial saliva corrosion medium will also corrode the base materials to some extent. Therefore, the coating coverage rate is very important to the corrosion resistance of CAW.

The definition of conductor resistance shows that $R_{\mathrm{ct}}$ value is inversely proportional to the surface area of the sample. We assume that the base material is the size of the unit and $\theta$ is the coverage rate, while the corroded area of samples by artificial saliva corrosion medium through micropore would be $(1-\theta)$. Then the $R_{\mathrm{ct}}$ of bare CAW and coated samples can be written as:

$$
\begin{gathered}
R_{\mathrm{ct}}^{0}=A^{0} / I \\
R_{\mathrm{ct}}=A /(1-\theta)
\end{gathered}
$$

where $R_{\mathrm{ct}}^{0}$ is the charge transfer resistance of CAW and $R_{\mathrm{ct}}$ is the one of coated samples. $A$ and $A^{0}$ are factors. Assuming $A$ and $A^{0}$ are the same, then the coverage rate $\theta$ can be derived as:

Table 3 Comparison of $R_{\mathrm{s}}, R_{\mathrm{ct}}, C_{\mathrm{dl}}$ and $\theta$ on different surfaces

\begin{tabular}{lllll}
\hline Sample & $R_{\mathrm{s}}\left(\Omega \mathrm{cm}^{2}\right)$ & $R_{\mathrm{ct}}\left(\mathrm{k} \Omega \mathrm{cm}^{2}\right)$ & $C_{\mathrm{cl}}\left(\mu \mathrm{F} \mathrm{cm}{ }^{-2}\right)$ & $\theta(\%)$ \\
\hline $\mathrm{CAW}$ & 33.5 & 758 & 6.34 & - \\
$\mathrm{TiO}_{2}$ & 40.5 & 10400 & 2.713 & 92.7 \\
$\mathrm{~N}^{-\mathrm{TiO}_{2}}$ & 46.1 & 43800 & 2.159 & 98.26
\end{tabular}




$$
1-\theta=R_{\mathrm{ct}}^{0} / R_{\mathrm{ct}}
$$

Yuan et al. have already used eqn (4) to calculate the coverage rate of the coated samples. ${ }^{45}$ From Table 3 the coverage rate of $\mathrm{TiO}_{2}$ and $\mathrm{N}-\mathrm{TiO}_{2}$ coated samples is $92.70 \%$ and $98.26 \%$, respectively. In this case the charge transfer resistance $\left(R_{\mathrm{ct}}\right)$ of N$\mathrm{TiO}_{2}$ will increase, as shown in Table 3. $R_{\mathrm{ct}}$ of N-TiO${ }_{2}$ was 43800 $\mathrm{k} \Omega \mathrm{cm}^{2}$, which is much larger than those of CAW and $\mathrm{TiO}_{2}-$ coated samples which were $10400 \mathrm{k} \Omega \mathrm{cm}^{2}$ and $758 \mathrm{k} \Omega \mathrm{cm}^{2}$, respectively.

According to comprehensive analysis of EIS results and Tafel curves, we can conclude that the coating $\mathrm{TiO}_{2}$ can improve the corrosion resistance of the wire. It is due to two points. One is that titanium dioxide is a kind of ceramic material, and its low conductivity can reduce the charge transport, thus improving the electrochemical barrier performance. ${ }^{46}$ The other is that the $\mathrm{TiO}_{2}$ film can effectively block the contact reaction between the substrate and the electrolyte. ${ }^{46}$ Meanwhile, we found the Ndoped $\mathrm{TiO}_{2}$ has a better property. Lindgren et al. reported that $\mathrm{N}$-doping can diminish the grain size of $\mathrm{TiO}_{2}$ and decrease the roughness of $\mathrm{TiO}_{2}$ thin film. ${ }^{47}$ As shown in Fig. $4 \mathrm{a}$ and b, Ndoped $\mathrm{TiO}_{2}$ thin film is more dense and compact, and its surface is smoother than that of un-doped $\mathrm{TiO}_{2}$ film because of its smaller grain size. The smaller the particle can decrease inter-particle distance and pore size of the films. The coverage rates of $\mathrm{TiO}_{2}$ and $\mathrm{N}$-doped $\mathrm{TiO}_{2}$ films showed in Table 3 also prove it. Thus the more compact structure and higher coverage rate of $\mathrm{N}$-doped $\mathrm{TiO}_{2}$ film can reduce micropore and seal channel better, which are more effective to prevent the contact between the electrolyte and the base material, and then hinder the occurrence of corrosion reaction. $R_{\mathrm{ct}}$ of $\mathrm{N}$-doped $\mathrm{TiO}_{2}$ is much larger than that of $\mathrm{TiO}_{2}$ also proves this point.

After electrochemical experiments, the color of the welding point of CAW becomes black and rough which can be seen by the naked eye. Fig. 8 shows corrosion image of the samples after electrochemical corrosion. Fig. $8 \mathrm{a}$ and $\mathrm{b}$ are the corrosion images of unmodified CAW after electrochemical etching, and a large area of corrosion can be found on the surface. It was observed from Fig. $8 \mathrm{~b}$ that not only the corrosion area is large but also the corrosion depth is deep and welding points are severely damaged. Some black areas and corrosion products on the un-doped $\mathrm{TiO}_{2}$ coated surface can be seen in Fig. 8c. This indicated that the un-doped $\mathrm{TiO}_{2}$ coated surface has also undergone mild corrosion behavior. As expected, for N-doped $\mathrm{TiO}_{2}$ coated CAW, its surface is still flat without obvious corrosion pits and corrosion product after electrochemical process, as demonstrated in Fig. 8d. The SEM results are in agreement with the electrochemical polarization curves and EIS results which indicate good corrosion resistance of $\mathrm{N}$-doped $\mathrm{TiO}_{2}$ coating.

\subsection{Antibacterial test}

Fig. 9 and 10 show the antimicrobial properties of each sample. It can be clearly seen that the group tested with $\mathrm{N}$-doped $\mathrm{TiO}_{2}$ thin film shows the most effective antimicrobial ability with

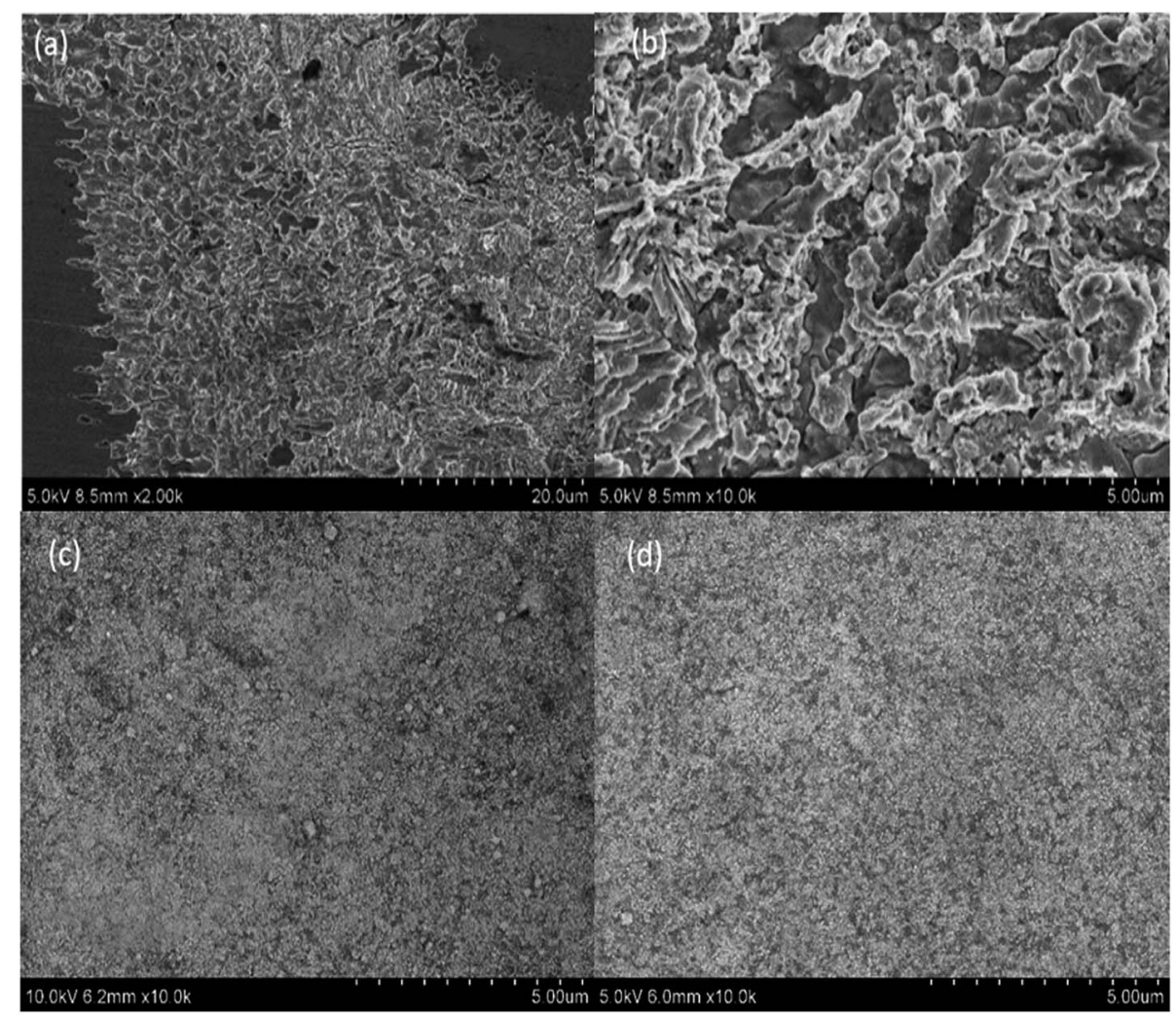

Fig. 8 SEM surface images of (a, b) CAW, (c) $\mathrm{TiO}_{2}$-coated CAW and (d) $\mathrm{N}$ - $\mathrm{TiO}_{2}$-coated CAW after potentiodynamic polarization tests. 


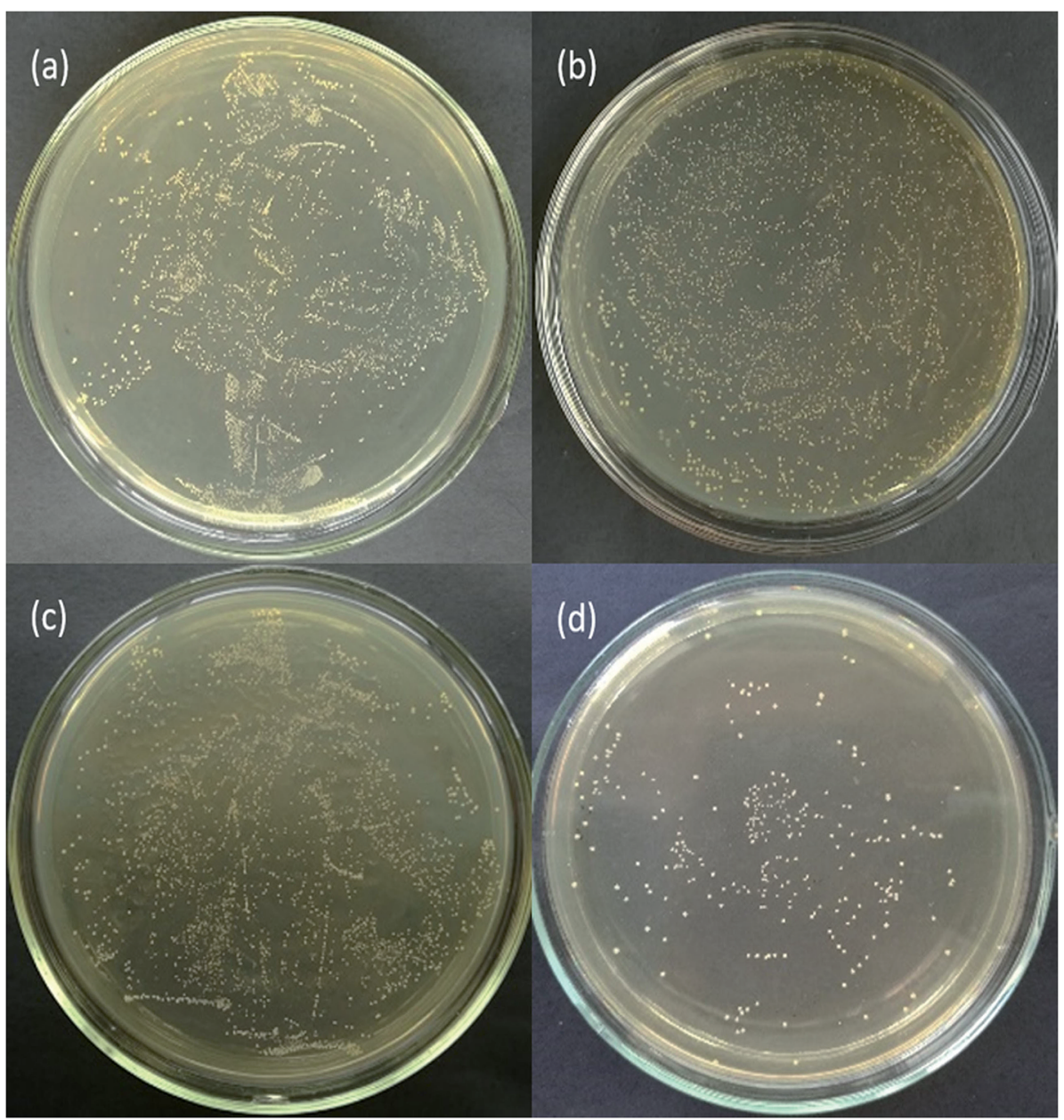

Fig. 9 Photographs of antimicrobial resistance of Streptococcus mutans: (a) control group, (b) CAW, (c) $\mathrm{TiO}_{2}$ and (d) $\mathrm{N}-\mathrm{TiO}_{2}$.

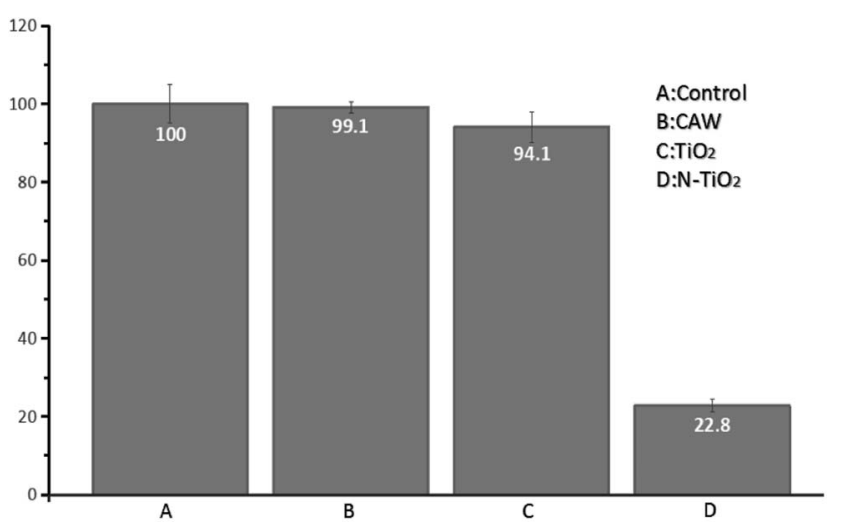

Fig. 10 Antibacterial effects of the samples against Streptococcus mutans.

a rate of $87.2 \%$. The group filmed only with $\mathrm{TiO}_{2}$ shows a rate of $5.9 \%$ which indicates no bactericidal effect according to standard reduction of bacteria criteria (standard reduction of bacteria criteria: less than $0-20 \%$ reduction indicates no bactericidal effect; $20-50 \%$ reduction indicates a low bactericidal effect; between $50 \%$ and $70 \%$ reduction indicates an expressive bactericide; and $>70 \%$ reduction is considered a powerful bactericidal effect ${ }^{35}$ ). Shuai Cao et al. have found that the photo-catalytic activities of $\mathrm{N}$-doped $\mathrm{TiO}_{2}$ substrates were much higher than that of un-doped $\mathrm{TiO}_{2}$ substrates. ${ }^{35}$ This finding coincides with our result. The main bactericidal mechanism of $\mathrm{TiO}_{2}$ was hydroxyl radical attack and the lipid peroxidation reaction. ${ }^{48}$ Huang et al. pointed out that when $\mathrm{TiO}_{2}$ photo-catalytic surface first contact with bacteria, the wall of the cell and the cytoplasmic membrane would be damaged, which would lead to the free efflux of intracellular contents. ${ }^{49}$ However, $\mathrm{TiO}_{2}$ only produces hydroxyl radical under irradiation with UV light. It has been demonstrated that $\mathrm{N}$-doped $\mathrm{TiO}_{2}$ is a visiblelight-sensitive photo-catalyst. In our experiments, the UV light has been filtered, thus the bactericidal rate of $\mathrm{TiO}_{2}$ is rather low whereas the bactericidal rate of $\mathrm{N}$-doped $\mathrm{TiO}_{2}$ filmed substrates is obvious under visible light irradiation.

Many patients might not be able to maintain oral hygiene during orthodontic treatment. This may cause the increase of the plaque accumulation around orthodontic arch wire, which leads to an increase of the possibility of caries. Streptococcus mutans is one of the main compositions of dental plaque. It can make use of sucrose for substrate to synthesize extracellular glucan, fructan and intracellular polysaccharide. Glucan which 
Table 4 The growth rate and the safety level of hamster fibroblasts in different time ${ }^{a}$

\begin{tabular}{|c|c|c|c|c|c|c|c|c|c|}
\hline \multirow[b]{2}{*}{ Group } & \multicolumn{3}{|l|}{$A$ value } & \multicolumn{3}{|c|}{ RGR (\%) } & \multicolumn{3}{|c|}{ Safety level } \\
\hline & $24 \mathrm{~h}$ & $72 \mathrm{~h}$ & $120 \mathrm{~h}$ & $24 \mathrm{~h}$ & $72 \mathrm{~h}$ & $120 \mathrm{~h}$ & $24 \mathrm{~h}$ & $72 \mathrm{~h}$ & $120 \mathrm{~h}$ \\
\hline Negative control & $0.449 \pm 0.035$ & $0.673 \pm 0.028$ & $1.147 \pm 0.035$ & 100 & 100 & 100 & 0 & 0 & 0 \\
\hline Positive control & $0.053 \pm 0.032 * *$ & $0.094 \pm 0.030^{* *}$ & $0.229 \pm 0.028 * *$ & 12 & 14 & 20 & 4 & 4 & 4 \\
\hline CAW & $0.431 \pm 0.026$ & $0.609 \pm 0.018^{* *}$ & $1.044 \pm 0.035^{*}$ & 96 & 90 & 91 & 1 & 1 & 1 \\
\hline $\mathrm{TiO}_{2}$ & $0.452 \pm 0.030$ & $0.66 \pm 0.019$ & $1.149 \pm 0.030$ & 101 & 98 & 101 & 0 & 1 & 0 \\
\hline $\mathrm{N}-\mathrm{TiO}_{2}$ & $0.474 \pm 0.034$ & $0.679 \pm 0.025$ & $1.169 \pm 0.080$ & 105 & 101 & 102 & 0 & 0 & 0 \\
\hline
\end{tabular}

is the important cause of caries can mediate bacteria adhesion and promote the formation of plaque, causing more bacteria to accumulate. Streptococcus mutans is also the main reason responsible for caries. It can ferment a variety of carbohydrates rapidly to produce a large quantity of acid which will make the local $\mathrm{pH}$ less than 5.5. Due to the protection of dental plaque, the buffer action of saliva could be easily avoided. Thus the decreased local $\mathrm{pH}$ can maintain for quite a long time which would cause local hard tissue demineralization. The caries will appear when the demineralization is severe enough. In our research the use of $\mathrm{N}$-doped $\mathrm{TiO}_{2}$ coated arch wire with high antibacterial activity under visible light irradiation would kill the most of Streptococcus mutans which is the main reason responsible for caries as stated above. This result indicated that $\mathrm{N}$-doped $\mathrm{TiO}_{2}$ modified compound arch wire has a high potential in the clinical practice.

\subsection{Cytotoxicity}

In order to realize the clinical application, the cytotoxicity of CAW, $\mathrm{TiO}_{2}$ and $\mathrm{N}$-doped $\mathrm{TiO}_{2}$-coated CAWs was respectively tested. The results are shown in the Table 4. The detailed procedures of the cytotoxicity tests are provided in ESI. $\dagger$ The relative growth rate (RGR) equals to the absorbance values of experimental group/the absorbance values of control group $\times$ $100 \%$. According to the calculated RGR shown in Table 4, the cytotoxicity levels of the three types of the materials are evaluated. Level 0: RGR $\geq 100 \%$; level 1: $75 \% \leq$ RGR $<100 \%$; level 2: $0 \% \leq$ RGR $<75 \%$; level $3: 25 \% \leq$ RGR $<50 \%$; level $4: 1 \% \leq$ RGR $<25 \%$; level 5: RGR $<1 \%$. Level 0 and level 1 are safe levels, while level 3-5 are unsafe levels. When the cytotoxicity is level 2, it should be further evaluated according to the status of the cell culture.

According to the literature report, ${ }^{6}$ the copper content should be less than $25 \%$ in the oral materials, although a small amount of copper can promote cell activity. The concentration of copper ions is greater than $10.85 \mathrm{mg} \mathrm{L}^{-1}$ for more than $24 \mathrm{~h}$, which will show the cytotoxicity. According to the results shown in Table 4, the safety level of CAW modified with N-doped $\mathrm{TiO}_{2}$ was 0 even though it was soaked in the solution for $120 \mathrm{~h}$. This result suggested that $\mathrm{N}$-doped $\mathrm{TiO}_{2}$ nanocrystal thin film can effectively prevent the release of $\mathrm{Cu}$ and $\mathrm{N}$-doped $\mathrm{TiO}_{2}$ modified CAW has good biological safety.

\section{Conclusions}

In summary, $\mathrm{TiO}_{2}$ and $\mathrm{N}$-doped $\mathrm{TiO}_{2}$ nanocrystal thin films were deposited on the surface of CAW by RF magnetron sputtering method. The morphologies and structures of the coated materials were systematically characterized and their corrosion resistance in artificial saliva was electrochemically assessed. As expected, the $\mathrm{TiO}_{2}$ and $\mathrm{N}-\mathrm{TiO}_{2}$ coated CAWs can greatly improve the corrosion resistance of pristine CAW in artificial saliva. It was demonstrated that $\mathrm{N}$-doped $\mathrm{TiO}_{2}$ film showed much better anticorrosion ability than $\mathrm{TiO}_{2}$ film. Additionally, the antibacterial experiments confirmed that $\mathrm{N}$-doped $\mathrm{TiO}_{2}$ group exhibited higher antibacterial activity against Streptococcus mutans with a rate of $87.2 \%$ under visible light irradiation. Therefore, the $\mathrm{N}$-doped $\mathrm{TiO}_{2}$ coating can improve corrosion resistance and antibacterial properties of CAW obviously. The results of the cytotoxicity test demonstrated that $\mathrm{N}$-doped $\mathrm{TiO}_{2}$ coated CAW has a high potential in the practical dental treatments.

\section{Conflicts of interest}

There are no conflicts to declare.

\section{Acknowledgements}

This work was supported by the National Natural Science Foundation of China (No. 50975122).

\section{References}

1 D. Q. Sun and H. M. Li, A New Method of TiNi Shape Memory Alloy and Austenitic Stainless Steel Different Kind of Material Connection, CN Patent, CNIO215201708, 2011.

2 C. Zhang and X. H. Sun, Susceptibility to Stress Corrosion of Laser-Welded Composite Arch Wire in Acid Artificial Saliva, Adv. Mater. Sci. Eng., 2013, 2013, 171-177.

3 C. W. Svare, G. Belton and E. Korostoff, The Role of Organics in Metallic Passivation, J. Biomed. Mater. Res., 1970, 4, 457467.

4 E. K. Fejerskov, Dental Caries: The Disease and Its Clinical Management, Wiley-Blackwell, 2nd edn, 2010, vol. 32, pp. 236-237. 
5 H. M. Li, D. Q. Sun, P. Dong and C. Liu, Microstructures and Mechanical Properties of Laser-Welded TiNi Shape Memory Alloy and Stainless Steel Wires, China Weld., 2010, 19, 1-5.

6 C. Zhang, X. Sun, S. Zhao, W. Yu and D. Sun, Susceptibility to Corrosion and In Vitro Biocompatibility of a Laser-Welded Composite Orthodontic Arch Wire, Ann. Biomed. Eng., 2014, 42, 222-230.

7 C. Zhang, S. Zhao, X. Sun, X. Sun and D. Sun, Corrosion of Laser-Welded NiTi Shape Memory Alloy and Stainless Steel Composite Wires with a Copper Interlayer upon Exposure to Fluoride and Mechanical Stress, Corros. Sci., 2014, 82, 404-409.

8 S. K. Nelson, J. C. Wataha, A. M. Neme, R. M. Cibirka and P. E. Lockwood, Cytotoxicity of Dental Casting Alloys Pretreated with Biologic Solutions, J. Prosthet. Dent., 1999, 81, 591-596.

9 G. N. Jenkins, The Physiology and Biochemistry of the Mouth, Blackwell Scientific Publications, Oxford Press, 1978.

10 R. L. Williams, S. A. Brown and K. Merritt, Electrochemical Studies on the Influence of Proteins on the Corrosion of Implant Alloys, Biomaterials, 1988, 9, 181-186.

11 J. Yang and J. Black, Competitive Binding of Chromium, Cobalt and Nickel to Serum Proteins, Biomaterials, 1994, 15, 262-268.

12 W. G. Zhang, W. M. Liu, Y. Liu and C. T. Wang, Tribological Behaviors of Single and Dual Sol-Gel Ceramic Films on Ti6Al-4V, Ceram. Int., 2009, 35, 1513-1520.

13 M. G. Mahmoud, R. G. Wang, M. Kato and K. Nakasa, Influence of Ultraviolet Light Irradiation on Corrosion Behavior of Weathering Steel with and without $\mathrm{TiO}_{2}$ Coating in 3 Mass\% NaCl Solution, Scr. Mater., 2005, 53, 1303-1308.

14 R. J. Koerner, L. A. Butterworth, R. D. Mayer and H. J. Busscher, Bacterial Adhesion to Titanium-oxy-nitride $\left(\right.$ TiNO $\left._{X}\right)$ Coatings with Different Resistivities: a Novel Approach for the Development of Biomaterials, Biomaterials, 2002, 23, 2835-2840.

15 R. Hübler, A. Cozza, T. L. Marcondes, R. B. Souza and F. F. Fiori, Wear and Corrosion Protection of $316-\mathrm{L}$ Femoral Implants by Deposition of Thin Films, Surf. Coat. Technol., 2001, 142-144, 1078-1083.

16 K. H. Chung, G. T. Liu, J. G. Duh and J. H. Wang, Biocompatibility of a Titanium-Aluminum Nitride Film Coating on a Dental Alloy, Surf. Coat. Technol., 2004, 188189, 745-749.

17 A. Balamurugan, S. Kannan and S. Rajeswari, Evaluation of $\mathrm{TiO}_{2}$ Coatings Obtained using the Sol-Gel Technique on Surgical Grade Type 316 L Stainless Steel in Simulated Body Fluid, Mater. Lett., 2005, 59, 3138-3143.

18 C. Valentin, E. Finazzi, G. Pacchioni, A. Selloni, S. Livraghi, M. C. Paganini and E. Giamello, N-Doped $\mathrm{TiO}_{2}$ : Theory and Experiment, Chem. Phys., 2007, 339, 44-56.

19 R. Asahi, T. Morikawa, T. Ohwaki, K. Aoki and Y. Taga, Visible-Light Photocatalysis in Nitrogen-Doped Titanium Oxides, Science, 2001, 293, 269-271.

20 N. T. Nolan, D. W. Synnott, M. K. Seery, S. J. Hinder, A. V. Wassenhoven and S. C. Pillai, Effect of N-Doping on the Photocatalytic Activity of Sol-Gel $\mathrm{TiO}_{2}, J$. Hazard. Mater., 2012, 211-212, 88-94.

21 F. Sayılkan, M. Asiltürk, N. Kiraz, E. Burunkaya, E. Arpac and H. Saylkan, Photocatalytic Antibacterial Performance of $\mathrm{Sn}^{4+}$-Doped $\mathrm{TiO}_{2}$ Thin Films on Glass Substrate, J. Hazard. Mater., 2009, 162, 1309-1316.

22 J. Zuo, P. Keil and G. Grundmeier, Synthesis and Characterization of Photochromic Ag-Embedded $\mathrm{TiO}_{2}$ Nanocomposite Thin Films by Non-Reactive RF-Magnetron Sputter Deposition, Appl. Surf. Sci., 2012, 258, 7231-7237.

23 C. G. Kuo, C. Y. Hsu, S. S. Wang and D. C. Wen, Photocatalytic Characteristics of $\mathrm{TiO}_{2}$ Films Deposited by Magnetron Sputtering on Polycarbonate at Room Temperature, Appl. Surf. Sci., 2012, 258, 6952-6957.

24 J. Zuo, Deposition of Ag Nanostructures on $\mathrm{TiO}_{2}$ Thin Films by RF Magnetron Sputtering, Appl. Surf. Sci., 2010, 256, 7096-7101.

25 D. Q. Sun, and H. M. Li., A New Method of TiNi Shape Memory Alloy and Austenitic Stainless Steel Different Kind of Material Connection, CN Patent, CNIO2152017, 2011.

26 F. Zhang, T. Zhang, X. Yang, L. Zhang, K. Leng, Y. Huang and Y. Chen, Synthesis and Supercapacitor Performance Studies of N-Doped Graphene Materials using $o$-Phenylenediamine as the Double-N Precursor, Energy Environ. Sci., 2013, 6, 1623.

27 R. P. Netterfeld, P. J. Martin, C. G. Pacey, W. G. Sainty, D. R. McKenzie and G. Auchterlonie, Ion-Assisted Deposition of Mixed $\mathrm{TiO}_{2}-\mathrm{SiO}_{2}$ Films, J. Appl. Phys., 1989, 66, 1805.

28 W. Zhang and D. Liu, Nitrogen-treated Hierarchical Macro-/ Mesoporous $\mathrm{TiO}_{2}$ Used as Anode Materials for Lithium Ion Batteries with High Performance at Elevated Temperatures, Electrochim. Acta, 2015, 156, 53-59.

29 J. Zheng, Y. Liu, G. Ji, P. Zhang, X. Cao, B. Wang, C. Zhang, X. Zhou, Y. Zhu and D. Shi, Synthesis and Structure of Nanocrystalline $\mathrm{TiO}_{2}$ with Lower Band Gap Showing High Photocatalytic Activity, ACS Appl. Mater. Interfaces, 2015, 7, 23431-23438.

30 Y. Yang, X. Ji, M. Jing, H. Hou, Y. Zhu, L. Fang, X. Yang, Q. Chen and C. E. Banks, Carbon Dots Supported upon NDoped $\mathrm{TiO}_{2}$ Nanorods Applied into Sodium and Lithium Ion Batteries, J. Mater. Chem. A, 2015, 3, 5648-5655.

31 M. Sathish, B. Viswanathan, R. P. Viswanath and C. S. Gopinath, N, S-co-Doped $\mathrm{TiO}_{2}$ Nanophotocatalyst: Synthesis, Electronic Structure and Photocatalysis, Chem. Mater., 2005, 17, 6349-6353.

$32 \mathrm{X}$. Chen and C. Burda, Photoelectron Spectroscopic Investigation of Nitrogen-Doped Titania Nanoparticles, $J$. Phys. Chem. B, 2004, 108, 15446-15449.

33 M. S. Wong, H. P. Chou and T. S. Yang, Reactively Sputtered N-Doped Titanium Oxide Films as Visible-Light Photocatalyst, Thin Solid Films, 2006, 494, 244-249.

34 S. Sakthivel, M. Janczarek and H. Kisch, Template-Free Synthesis of Mesoporous N-Doped $\mathrm{SrTiO}_{3}$ Perovskite with High Visible-Light-Driven Photocatalytic Activity, J. Phys. Chem. B, 2004, 108, 19384-19387. 
35 C. Shuai, L. Bo and F. Ling, Highly Antibacterial Activity of Ndoped $\mathrm{TiO}_{2}$ Thin Films Coated on Stainless Steel Brackets under Visible Light Irradiation, Appl. Surf. Sci., 2014, 309, 119-127.

36 A. Baron, W. Simka, G. Nawrat and D. Szewieczek, Electropolishing and Chemical Passivation of Austenitic Steel, J. Achiev. Mater. Manuf. Eng., 2008, 31, 197-202.

37 H. Q. Liu, Y. X. Leng, G. J. Wan and N. Huang, Corrosion Susceptibility Investigation of Ti-O Film Modified CobaltChromium Alloy (L-605) Vascular Stents by Cyclic Potentiodynamic Polarization Measurement, Surf. Coat. Technol., 2011, 206, 893-896.

38 T. Kokubo and H. Takadama, How Useful is SBF in Predicting in vivo Bone Bioactivity?, Biomaterials, 2006, 27, 2907-2915.

39 X. P. Ouyang, X. Q. Qiu, H. M. Lou and D. J. Yang, Corrosion and Scale Inhibition Properties of Sodium Lignosulfonate and Its Potential Application in Recirculating Cooling Water System, Ind. Eng. Chem. Res., 2006, 45, 5716e5721.

40 D. Y. Yu, J. T. Tian, J. H. Dai and X. Wang, Corrosion Resistance of Three-Layer Super Hydrophobic Composite Coating on Carbon Steel in Seawater, Electrochim. Acta, 2013, 97, 409e419.

41 A. L. Rudd, C. B. Breslin and F. Mansfeld, The Corrosion Protection Afforded by Rare Earth Conversion Coatings Applied to Magnesium, Corros. Sci., 2000, 42, 275.

42 N. Peebre, T. Picaud, M. Duprat and F. Dabosi, Evaluation of Corrosion Performance of Coated Steel by the Impedance Technique, Corros. Sci., 1989, 29, 1073.
43 M. Metikos-Hukovic, E. Tkalcec, A. Kwokal and J. Piljac, An in vitro Study of $\mathrm{Ti}$ and Ti-Alloys Coated with Sol-Gel Derived Hydroxyapatite Coatings, Surf. Coat. Technol., 2003, 165, 40.

44 F. Belluci and L. Nicodemo, Water Transport in Organic Coatings, Corrosion, 1993, 49, 235.

45 S. J. Yuan, S. O. Pehkonen, B. Liang, Y. P. Ting, K. G. Neoh and E. T. Kang, Superhydrophobic Fluoropolymer-modified Copper Surface via Surface Graft Polymerisation for Corrosion Protection, Corros. Sci., 2012, 53, 2738.

46 H. Wang, R. Zang, Z. Yuan, X. Shu, E. Liu and Z. Han, A Comparative Study of the Corrosion Performance of Titanium (Ti), Titanium Nitride (TiN), Titanium Dioxide $\left(\mathrm{TiO}_{2}\right)$ and Nitrogen-Doped Titanium Oxides $\left(\mathrm{N}-\mathrm{TiO}_{2}\right)$, as Coatings for Biomedical Applications, Ceram. Int., 2015, 41, 11844-11855.

47 T. Lindgren, J. M. Mwalnra, E. Avendano, J. Jonnson, A. Hoel, C. Granqvist and S. Lindquist, Photoelectrochemical and Optical of Nitrogen-Doped Titallium Dioxide Films Prepared by Reactive DC Magnetron Sputtering, J. Phys. Chem. B, 2003, 107, 5709-5716.

$48 \mathrm{X}$. Wang, X. Hou, W. Luan, D. Li and K. Yao, The Antibacterial and Hydrophilic Properties of Silver-Doped $\mathrm{TiO}_{2}$ Thin Films using Sol-Gel Method, Appl. Surf. Sci., 2012, 258, 8241-8246.

49 P. C. Maness, S. Smolinski, D. M. Blake, Z. Huang, E. J. Wolfrum and W. A. Jacoby, Bactericidal Activity of Photocatalytic $\mathrm{TiO}_{2}$ Reaction: Toward an Understanding of Its Killing Mechanism, Appl. Environ. Microbiol., 1999, 65, 4094-4098. 